\title{
Fabrication of Tissue Engineering Scaffolds Using Marine Bioactive Materials for Diverse Applications
}

\author{
Thangamani Santhana Vignesh ${ }^{\dagger}$, Cheruvathoor Poulose Suja ${ }^{\ddagger *}$, and Subramanian Geetha ${ }^{\dagger}$ \\ $\dagger$ University College of Engineering, BIT Campus \\ Anna University Tiruchirapalli, Tamil Nadu, India \\ Tuticorin Research Centre of ICAR- \\ Central Marine Fisheries Research Institute \\ Tuticorin, Tamil Nadu, India
}

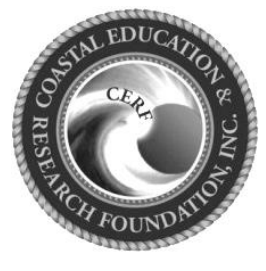

www.cerf-jcr.org

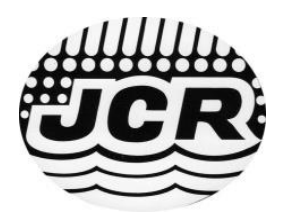

www.JCRonline.org

\begin{abstract}
Vignesh, T.S.; Suja, C.P., and Geetha, S., 2019. Fabrication of tissue engineering scaffolds using marine bioactive materials for diverse applications. In: Jithendran, K.P.; Saraswathy, R.; Balasubramanian, C.P.; Kumaraguru Vasagam, K.P.; Jayasankar, V.; Raghavan, R.; Alavandi, S.V., and Vijayan, K.K. (eds.), BRAQCON 2019: World Brackishwater Aquaculture Conference. Journal of Coastal Research, Special Issue No. 86, pp. 170-176. Coconut Creek (Florida), ISSN 0749-0208.
\end{abstract}

\begin{abstract}
Scaffolds are polymeric matrices employed in delivering cells and drugs into human body. The scaffold matrices can be fabricated using natural or chemical polymers. In the present study, natural polymers and biomineralized materials extracted from marine sources have been used in the fabrication of the scaffolds. Marine biomaterials are highly biocompatible and they have been used for medicinal purposes. Hence the study focuses on fabricating a novel molluscan nacre incorporated scaffold, using biomaterials like $\boldsymbol{\kappa}$-carrageenan from Kappaphycus alvarezii, collagen from Sepia lycidas and chitosan from shrimp shell by freeze-drying method. Due to the osteogenic and dermal regeneration properties of nacre, this novel scaffold can be used for tissue engineering applications. The extracted natural polymers used in fabricating the scaffolds were analyzed by Fourier Transform Infrared Spectroscopy (FTIR). The FTIR analysis of the sulfated polysaccharide $\boldsymbol{\kappa}$-carrageenan showed strong absorbance peaks along $926 \mathrm{~cm}^{-1}$ and $1250 \mathrm{~cm}^{-1}$ which correspond to 3,6 anhydro-d-galactose and sulphur bonds respectively whereas the deacetylated polysaccharide chitosan showed peaks along the $3428 \mathrm{~cm}^{-1}$ and $1635 \mathrm{~cm}^{-1}$ corresponding to $\mathrm{OH}$ groups and secondary amine groups. FTIR analysis of collagen exhibited characteristic peaks along $3432 \mathrm{~cm}^{-1}$ and $1641 \mathrm{~cm}^{-1}$ indicating the presence of the amine groups and hydrogen bonds. The structural morphology of the fabricated scaffold has been analyzed by Scanning Electron Microscopy (SEM). These scaffolds have wide scope in diverse areas and will be a useful model of 3D cell culture for engineering edible meat, tissues and organs.
\end{abstract}

ADDITIONAL INDEX WORDS: $3 D$ cell culture, edible meat, marine biomaterials, nacre, scaffold, tissue engineering.

\section{INTRODUCTION}

Tissue engineering is a field of science that combines cells, scaffolds and bioactive materials to create functional threedimensional tissues (Garg et al., 2012). This interdisciplinary field involves thrust areas of cell biology, material science, chemistry, molecular biology, engineering and medicine. The scaffold plays a major role in tissue engineering. Hence fabricating a biocompatible scaffold is a key factor for the success of engineering a tissue. Scaffolds are polymeric matrices where the cells adhere, grow and remain viable. The main aim of using a scaffold in cell culture is to provide in vivo microenvironment to the cells in laboratory conditions. These porous structures comprise the biochemical, biophysical and biomechanical cues that help in the cell proliferation, maintenance, differentiation and functioning (Sala et al., 2013). Scaffolds are fabricated from a variety of natural and synthetic biomaterials. The biocompatible nature of the scaffold depends upon the biomaterial used. Natural biomaterials extracted from plants, animals and microbes may be either protein based or polysaccharide-based (Ha et al., 2013).

DOI: 10.2112/SI86-026.1 received 11 April 2019; accepted in revision 14 May 2019.

*Corresponding author: cpsuja@gmail.com

${ }^{\circ}$ Coastal Education and Research Foundation, Inc. 2019
Commonly used natural biomaterials are collagen, alginate, chitosan and hyaluronic acid. The marine environment houses exotic sources of marine biomaterials. The major sources of marine biomaterials like collagen, chitosan and carrageenan are from fish, molluscs, crustaceans and algae. Most of the marine biomaterials are highly biocompatible and have found application in the field of tissue engineering (Venkatesan and Kim, 2011).

Collagen is one among the most abundant proteins present in both vertebrates and invertebrates. Collagens are constituted with the repeated triplets Gly-X-Y of glycine and two other amino acids, where proline and hydroxyproline (Hyp) are the most common. They act as a ligand for the cell receptors found on the surface of the cells. Scaffolds fabricated using collagen facilitates the adherence, proliferation and growth of the cells in vitro and has the ability to allow the adherence and proliferation of cells within the scaffold (Silva et al., 2014). Chitosan is a cationic polymer obtained from chitin comprising copolymers of $\beta(1 \rightarrow 4)$-glucosamine and $\mathrm{N}$-acetyl-D-glucosamine. The amino and hydroxyl groups of the chitosan can be modified chemically which provides high stability to the molecules and makes it metabolizable by the human system. Chitosan can mimic the structural characteristics of the glycosaminoglycans (Sharma and Chandy, 1990). Carrageenan is a sulphated polysaccharide of the galactans group with alternating 1,3 and 1,4 linked 
galactose residues. Carrageenan possesses sulphate groups which mimic the chondroitin sulphate component of the extracellular matrix (ECM). This component of the ECM helps in cell differentiation ( $\mathrm{Li}$ et al., 2014). Nacre is a biomineralized material secreted by the mantle cells of the molluscs. They are calcified structures that form the inner lustrous layer. It is made up of the aragonite tile surrounded by organic matrix. The organic matrix of the nacre is composed of the polysaccharides and proteins. Water-Soluble Matrix (WSM) of nacre is also known to help in osteogenic regeneration and can be employed in treatment of burn injuries (Moutahir et al., 2001).

In the present study, the biomaterials used in the fabrication of the scaffold are carrageenan from Kappaphycus alvarezii, chitosan from crustacean shells, collagen from skin of Sepia lycidas and WSM of nacre from shells of Pinctada fucata. They were employed in the fabrication of the scaffold with a view to represent various components of the ECM.

\section{METHODS}

\section{Extraction and Characterization of the Biomaterials}

Chitosan was extracted from the shrimp exoskeleton by a modified procedure of Toan (2009). Fresh shrimp shells of Penaeus sp. were collected from the local market of Tuticorin, Tamil Nadu. Exoskeleton of the shrimp was separated and washed with fresh water. The collected shell was then dried in shade for 24 hours. Dried shells were taken and then ground well using a blender, followed by demineralization using $3 \%$ hydrochloric acid, deproteination using $4 \%$ sodium hydroxide and deacetylation using $60 \%$ sodium hydroxide. The resultant flakes were dried and characterized.

Collagen was obtained from the outer skin of Sepia lycidas (Nagai et al., 2001). The cuttle fish was collected from the Tharuvaikulam Landing Centre of Tuticorin district of Tamil Nadu. The skin was separated and treated with $0.1 \mathrm{M}$ sodium hydroxide for three days followed by treatment with acetic acid. The acid solubilized collagen was separated from the acid by salting out technique and the precipitate was dialyzed and lyophilized. The lyophilized protein sample was then characterized.

Carrageenan was isolated from the macro algae Kappaphycus alvarezii by the method of Istini, Ohno, and Kusunose (1994). The algae were collected from the Mullakadu coast of Tuticorin district and dried. The dried samples were treated with $6 \%$ potassium hydroxide and boiled to obtain a gelatinous liquid which was then filtered. The filtered liquid was treated with absolute alcohol and the resultant precipitate was dried and characterized.

The extracted biomaterials were characterized using Fourier Transform Infrared Spectroscopy (FT-IR). Infrared spectra were taken for the synthesized biomaterials using FTIR to determine the functional groups present in the biomaterials. The FTIR Spectra was measured using Perklin Elmer Spectrum GX2000. The FTIR spectra were recorded in the transmittance mode over the wave range of $4000 \mathrm{~cm}^{-1}-400 \mathrm{~cm}^{-1}$. The FTIR Spectra were interpreted as per Coates (2006).

The biomineralized material, nacre, was extracted from the shells of the pearl oyster, Pinctada fucata and powdered. Two grams of shell powder was dissolved in $200 \mathrm{ml}$ PBS and mixed overnight. The mixture was centrifuged and the supernatant was lyophilized. The lyophilized Water Soluble Matrix (WSM) was used in the fabrication of the scaffold.

\section{Preparation of the Collagen Chitosan Carrageenan WSM (CCCW) Scaffold}

Collagen $(0.5 \%)$ and chitosan $(0.5 \%)$ were dissolved in $1 \%$ acetic acid, mixed in equal volumes (1:1) under aseptic conditions and stored. Carrageenan (1\%) was prepared by dissolving in $0.15 \mathrm{M}$ potassium chloride solution. The prepared carrageenan was mixed with the collagen chitosan mixture in the ratio of 7.5:2.5 and stirred continuously for 12 hours under constant speed. After 12 hours, the mixture was added with $1 \%$ WSM. The mixture was again mixed for several hours. After mixing, the polymeric composite was poured into a glass beaker and frozen at $-30^{\circ} \mathrm{C}$ overnight. The frozen polymeric mixture was then lyophilized for 8 hours. Following this, the scaffold was further treated with ethanol for crosslinking and again lyophilized. The final scaffold was used for analysis.

\section{Physiochemical Properties}

The chemical characteristics of the CCCW scaffold was determined by FTIR spectroscopy and the thermal properties were determined by means of the Thermogravimetric analysis. The experiment was done at a heating rate of $10^{\circ} \mathrm{C} / \mathrm{min}$ within a temperature range of $30^{\circ} \mathrm{C}-350^{\circ} \mathrm{C}$. The microstructure and morphology of scaffolds were analysed using a Scanning Electron Microscope (TESCAN Vega3 SEM). Dried scaffolds were sputter-coated with gold at 40mA (JEOL-JFC1200E) prior to observing under SEM.

\section{Swelling Ratio}

Six scaffolds of same weight were taken $\left(\mathrm{W}_{0}\right)$ and immersed in $2 \mathrm{ml}$ of PBS and incubated at $27^{\circ} \mathrm{C}$. The swelling ratio was observed at a time interval of 24 hours up to the next 144 hours. The scaffolds were taken out from the buffer and weighed. The excess buffer on the surface of the scaffold was removed by wiping it with a sterile tissue paper and the final weight of the scaffold was noted $\left(\mathrm{W}_{\mathrm{F}}\right)$. The swelling ratio of the scaffold was calculated using the following equation;

$$
\text { Swelling Ratio }=\left(\mathrm{W}_{\mathrm{F}}-\mathrm{W}_{0}\right) / \mathrm{W}_{0}
$$

\section{Degradation Rate}

Five scaffolds of same weight were taken $\left(\mathrm{W}_{0}\right)$ and immersed in $2 \mathrm{ml}$ of MEM medium and incubated at $27^{\circ} \mathrm{C}$ for 120 hours at a time interval of 24 hours. The scaffolds were taken out from the medium. The resultant scaffold was dried and the final weight of the scaffold was noted $\left(\mathrm{W}_{\mathrm{F}}\right)$. The degradation rate of the scaffold was calculated using the following equation;

$$
\text { Degradation Rate }=\left(\mathrm{W}_{0}-\mathrm{W}_{\mathrm{F}}\right) / \mathrm{W}_{\mathrm{F}}
$$

\section{Protein Absorption Capacity}

The protein absorption capacity of the scaffold was determined by soaking the scaffold in standard protein solution of known concentration. Bovine Serum Albumin (BSA) was used as the standard protein and the protein absorption capacity of the scaffold over time was estimated. The scaffold was soaked for a total of 120 hours and it was taken out at a time 


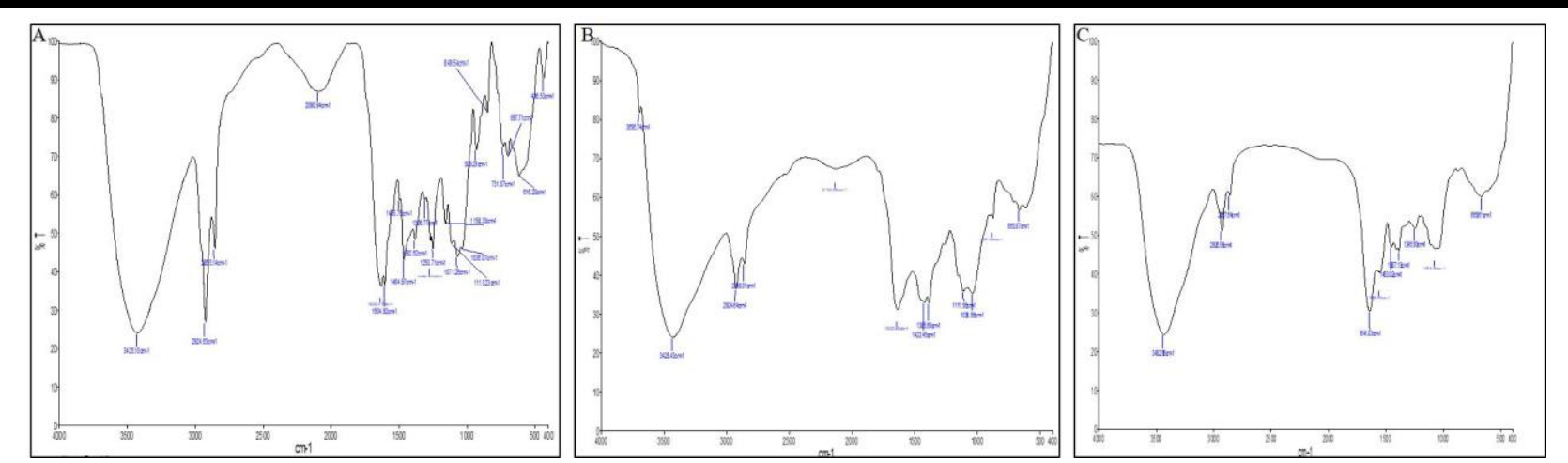

Figure 1. FTIR spectra of extracted biomaterials A) carrageenan, B) chitosan, C) collagen.

interval of 24-hour intervals. The proteins adsorbed onto the surface of the scaffold were washed with PBS twice followed by soaking the scaffold in $1 \%$ SDS for two hours to elute the absorbed protein. The solution was then taken and read at 280 $\mathrm{nm}$ to determine the total protein absorbed.

\section{Isolation and Maintenance of Fish Muscle Cells}

The white muscle cells of the fish were isolated from Trachinotus blochii by a modified procedure of Dodson et al. (2008). The fish was anesthetized and sacrificed. The surface of the fish was sterilized using $70 \%$ ethanol, followed by PBS containing antibiotics. The white muscle from fish was excised, rinsed well in PBS containing antibiotics and again washed in sterile PBS with antibiotics by centrifuging at $10000 \mathrm{rpm}$ for 10 minutes. The procedure was repeated twice. The washed tissue was then minced well, treated with collagenase enzyme at $27^{\circ} \mathrm{C}$ for 2 hours, centrifuged and the pellet was taken and washed twice with PBS and once with PBS containing antibiotics. The supernatant from the above step was taken and centrifuged. The resulting pellet was suspended in medium (MEM) containing $15 \%$ FCS and incubated at $27^{\circ} \mathrm{C}$ with $5 \% \mathrm{CO}_{2}$. The cells were then passaged continuously and maintained.

\section{Biocompatibility of Scaffold with Muscle cells of Trachinotus blochii}

A twelve well plate with MEM medium was taken and the scaffolds were placed in each well of the plate, after being heated at $60^{\circ} \mathrm{C}$ for 30 minutes and exposed to UV radiation. A volume of $0.5 \mathrm{ml}\left(1 \times 10^{5}\right.$ cells ml-1) of muscle cells was added into the wells with the scaffolds. The viability of the cells was monitored routinely by Trypan Blue Dye Exclusion Assay (Tolnai, 1975) and the compatibility of the cells with the scaffolds was determined.

\section{RESULTS}

Isolation and Characterization of the Marine Bioactive Compounds

The marine bioactive compounds, carrageenan, chitosan, collagen and WSM of the nacre were extracted and characterized by FTIR spectroscopy. The yield of carrageenan extracted from $K$. alvarezii was about $36.5 \%(\mathrm{w} / \mathrm{w})$ of the total weight. The FTIR spectrum of the extracted carrageenan showed peaks corresponding to different functional groups (Figure 1A).
The peak at $3425.10 \mathrm{~cm}^{-1}$ indicated the presence of O-H groups. The peaks along $2924.63 \mathrm{~cm}^{-1}$ and $2855.14 \mathrm{~cm}^{-1}$ showed the presence of C-H groups. The peak at $2090.94 \mathrm{~cm}-1$ showed the presence of thiocyanite ions. The peak at $1632.47 \mathrm{~cm}^{-1}$ showed the presence of N-H groups. The peak at $1604.92 \mathrm{~cm}^{-1}$ indicated the presence of C-O groups. The peaks along $1495.75 \mathrm{~cm}^{-1}$ and $1464.97 \mathrm{~cm}^{-1}$ indicated the presence of $\mathrm{NH}^{3+}$ and $\mathrm{C}=\mathrm{S}$ groups respectively. The peak along $1382.62 \mathrm{~cm}^{-1}$ showed the presence of C-H groups. The peaks at $1268.47 \mathrm{~cm}-1$ and $1250.71 \mathrm{~cm}-1$ confirmed the presence of $\mathrm{C}-\mathrm{O}$ groups. The peak at $1158.33 \mathrm{~cm}$ ${ }^{1}$ showed the presence of $\mathrm{C}-\mathrm{H}$ groups. The peak along 1071.26 $\mathrm{cm}^{-1}$ and $1036.07 \mathrm{~cm}^{-1}$ showed the P-O-C groups and $\mathrm{S}=\mathrm{O}$ groups, respectively. The characteristic peak along $849.54 \mathrm{~cm}^{-1}$ indicating the bending of secondary sulphate groups on $\mathrm{C} 4$ of the galactose sugar and $929.29 \mathrm{~cm}^{-1}$ showing the stretching of C$\mathrm{O}$ group due to the presence of the 3,6 anhydro-galactose in the compound (Pereira et al., 2009) confirms that the extracted compound is $\boldsymbol{\kappa}$-carrageenan (Chopin and Whalen, 1993).

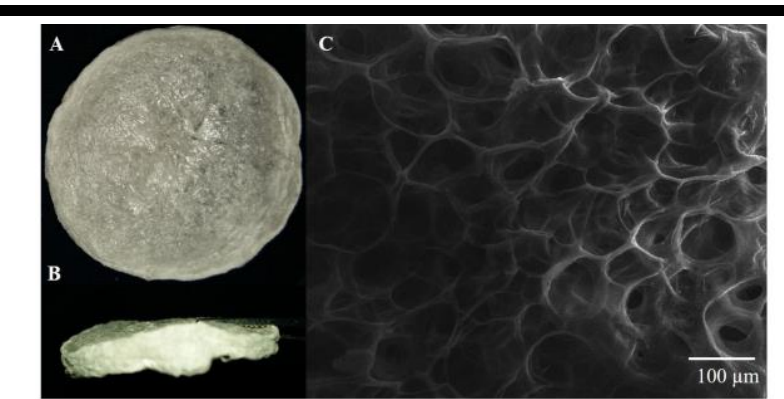

Figure 2. A) Photographic image of the fabricated CCCW scaffold, B) Side view of scaffold showing thickness of the scaffold, C) Microstructure of CCCW scaffold observed under Scanning Electron Microscope.

The shrimp shells were processed for the production of chitosan and the yield was about $20 \%$ (w/w) of the total weight. The FTIR spectrum of the extracted chitosan was analysed using FTIR spectroscopy (Figure 1B). The spectrum showed peaks along $3428.43 \mathrm{~cm}^{-1}$ which was due to the presence of $\mathrm{O}-\mathrm{H}$ and $\mathrm{N}-\mathrm{H}$ groups in the chitosan. The peaks along $2924.64 \mathrm{~cm}^{-1}$ and $2858.01 \mathrm{~cm}^{-1}$ showed the presence of $\mathrm{C}-\mathrm{H}$ groups. The weak peak at $2134.45 \mathrm{~cm}^{-1}$ showed the $\mathrm{C}=\mathrm{C}$ groups. The peak along 

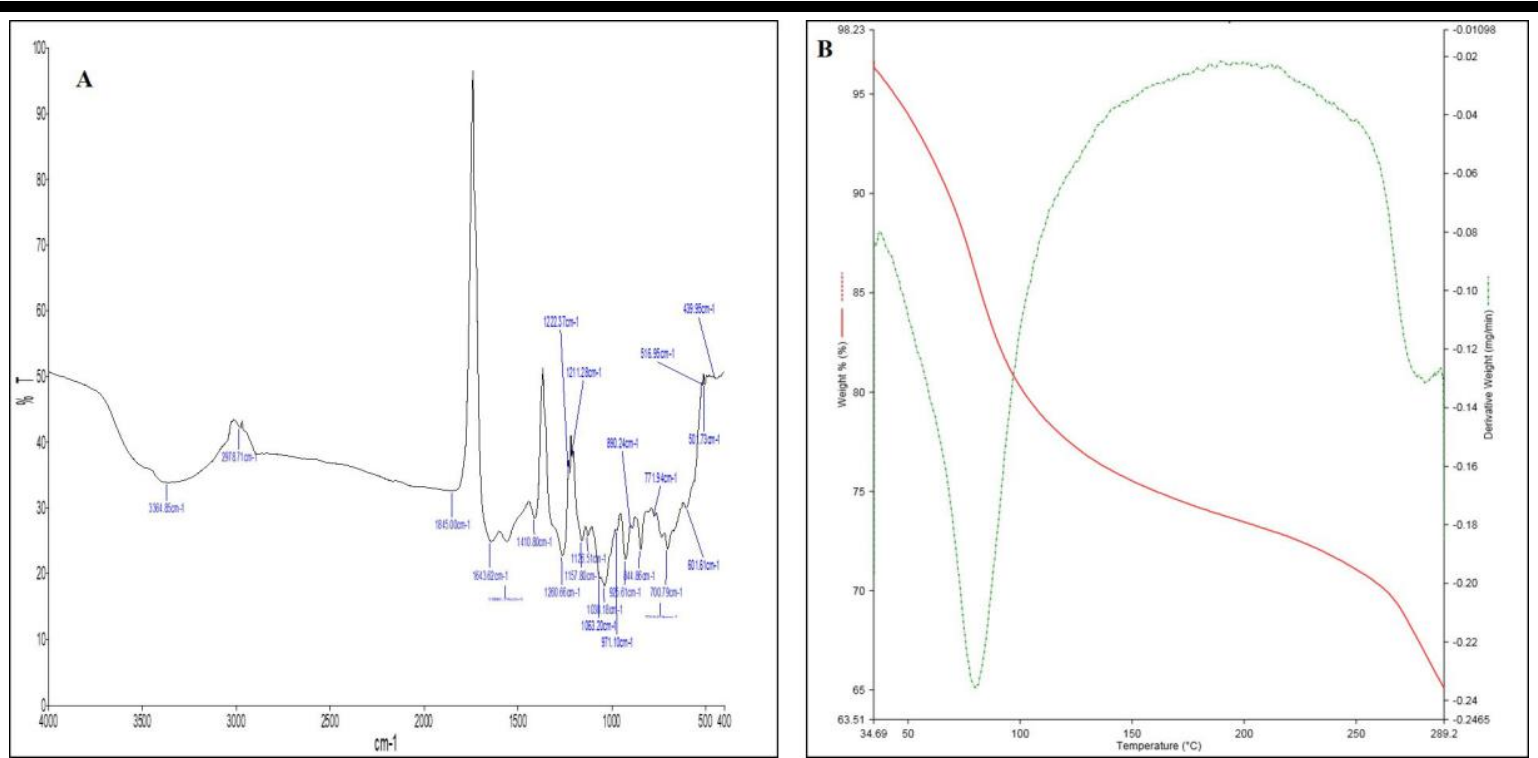

Figure 3. A) FTIR spectrum of the CCCW scaffold, B) Thermogram of CCCW scaffold.

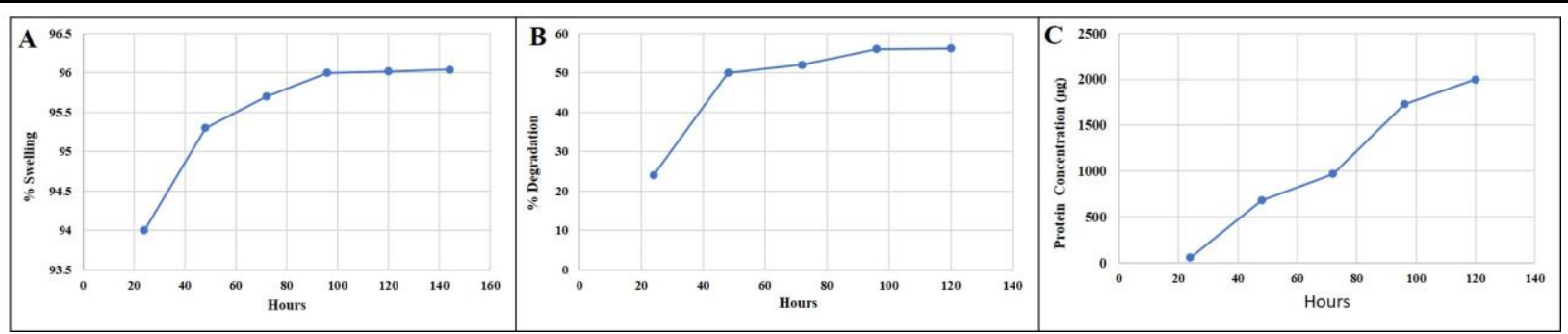

Figure 4. A) Graph showing the swelling ratio of CCCW scaffold in PBS (pH 7.4), B) Graph showing the degradation of the scaffold in the medium, and C) Graph showing the protein absorption rate of the scaffold.

$1635.95 \mathrm{~cm}^{-1}$ showed the presence of $\mathrm{C}=\mathrm{C}$ groups. The peaks along $1423.45 \mathrm{~cm}^{-1}$ and $1385.68 \mathrm{~cm}^{-1}$ showed the presence of methyl groups. The characteristic peaks along $1635.95 \mathrm{~cm}^{-1}$ indicating the presence of Carbonyl group (Teli and Sheik, 2012) and $3428.43 \mathrm{~cm}^{-1}$ indicating the presence of amide group (Varun et al., 2017) were observed.

Further the presence of peaks along $877.27 \mathrm{~cm}^{-1}$ in the obtained spectrum indicates the Pyranose sugar stretching showing that the polysaccharide was Chitosan. The yield of collagen extracted from the skin of S. lycidas was about $2.5 \%$ (w/w). The FTIR spectrum of collagen (Figure 4C) showed peaks along $2926.56 \mathrm{~cm}^{-1}$ which was due to the $\mathrm{CH}_{2}$ group in the extracted compound.

The peaks along $2857.64 \mathrm{~cm}^{-1}$ and $1641.03 \mathrm{~cm}^{-1}$ ed the presence of $\mathrm{CH}_{2}$ group and $\mathrm{C}=\mathrm{O}$ groups, respectively. The peak along $1553.69 \mathrm{~cm}^{-1}$ and $1453.02 \mathrm{~cm}^{-1}$ indicated the presence of $\mathrm{NH}$ bend and $\mathrm{CH}_{2}$ bend, respectively. The peaks along 1387.13 $\mathrm{cm}^{-1}, 1245.93 \mathrm{~cm}^{-1}$ and $1074.76 \mathrm{~cm}-1$ showed the presence of wagging of $\mathrm{CH}_{2}$ group, $\mathrm{NH}$ group and $\mathrm{C}-\mathrm{O}$ group, respectively. These peaks were closely in correspondence to peaks observed in other collagens. Hence, it is inferred that the extracted protein is collagen.

\section{Fabrication of the Scaffold}

The polymeric mixtures used in the fabrication of the scaffolds are usually oppositely charged. However, carrageenan, chitosan and collagen when mixed form strong insoluble precipitates. This was prevented by adding potassium chloride to the mixture. The fabricated scaffold was white in colour and inelastic in nature. The wet scaffold was softer and showed elasticity. The thickness of the scaffold was found to be $1.5 \mathrm{~mm}$.

\section{Physiochemical Properties}

The chemical composition of the scaffold analyzed using the FTIR analysis showed the changes in absorption peaks of different functional groups. The shifts in the peaks were mainly due to the interaction of the various functional groups. Similarly, the Thermogram of the scaffold also showed its thermal stability under various temperatures. The microstructure of the scaffolds observed under Scanning Electron Microscope revealed the 
porous nature of the scaffold. The scaffold had pore size ranging from $19-44 \mu \mathrm{m}$ in diameter.

\section{Swelling Ratio}

Swelling ratio of the scaffold was estimated by incubating the scaffold at $27^{\circ} \mathrm{C}$ in PBS. Figure 4A shows the swelling profile of the scaffold. The swelling ratio of the scaffold increased rapidly to $94 \%$ after 24 hours of incubation. A gradual increase in the swelling ratio was observed after 48 hours. The swelling ratio reached its saturation after 96 hours.

\section{Degradation Rate}

The degradation of the scaffold was analyzed by incubating the scaffold in MEM medium. The degradation of the scaffold was observed for 5 days. The degradation rate of the scaffold is shown in Figure. 4B. About $24 \%$ of the scaffold was found to be degraded after 24 hours and 56\% of the scaffold after 96 hours. The rest of the scaffold was intact even after two weeks.

\section{Protein Absorption Capacity}

The protein absorption into the scaffold increased gradually over time (Figure 4C). A maximum of $2000 \mu \mathrm{g}$ of protein was found to be absorbed on to the scaffold at the 120th hour. The porosity of the scaffold also plays a major role in its protein absorption capacity and the protein absorption also reaches a saturation point. However, the scaffold protein absorption rate was appreciable and seemed to meet the requirement necessary for a tissue engineered scaffold.

\section{Biocompatibility of Scaffold with Muscle cells of Trachinotus blochii}

The isolated fish cells were inoculated along with the fabricated scaffold and the compatibility was assessed. The viability of the cells was checked continuously and was found to be greater than $90 \%$ for 120 hours. The cells were seen to surround the scaffold (Figure 5) and did not move away thereafter. The scaffold promoted the growth of fish cells, and formation of the muscle fibers was seen on the fifth day (Figure $5 \mathrm{~F}$ ) indicating its biocompatibility with the fish cells.

\section{DISCUSSION}

The CCCW scaffold fabricated using the extracted marine biomaterials were found to be biocompatible, with enhanced swelling and protein absorption properties. The polysaccharide present in the scaffold influences the properties of the scaffolds to a greater extent. Li et al. (2014) reported that carrageenan can improve the swelling ratio and mechanical strength of the scaffold. The larger the water holding capacity of the scaffold the greater will be the efficiency of the scaffold in vitro. In this study, swelling ratio increased up to 96 hours. The higher absorption of water by the scaffold was mainly due to the water absorption capacity of the carrageenan, which is present in larger amounts in the scaffold.

Protein adsorption capacity of the scaffold is a parameter for the tissue engineering application, as the scaffold must have the capacity to absorb proteins from the medium thus facilitating the cells to utilize the protein and grow within the scaffold. The proteins may also include the growth factors and other proteins which are supplemented through the medium. Chen et al. (2016) reported that incorporation of nacre in the scaffold enhances the protein absorption capacity of the scaffolds. Liu, Huang, and Feng (2013) incorporated pearl powder into the scaffolds. After the addition of the pearl powder a change in the pore size of the scaffold was observed. They reported that the pearl powder in the scaffold improved the mechanical properties of the scaffolds. Hence WSM of nacre was used in this study to infer its impact on the scaffold.

Other polysaccharides such as alginate when incorporated into the scaffold improve the degradability of the scaffold (Chen et al., 2016). The carrageenan component of the scaffold plays a major role in decelerating the degradation rate of the scaffold. Controlled degradability of the scaffold is also necessary for an efficient scaffold.

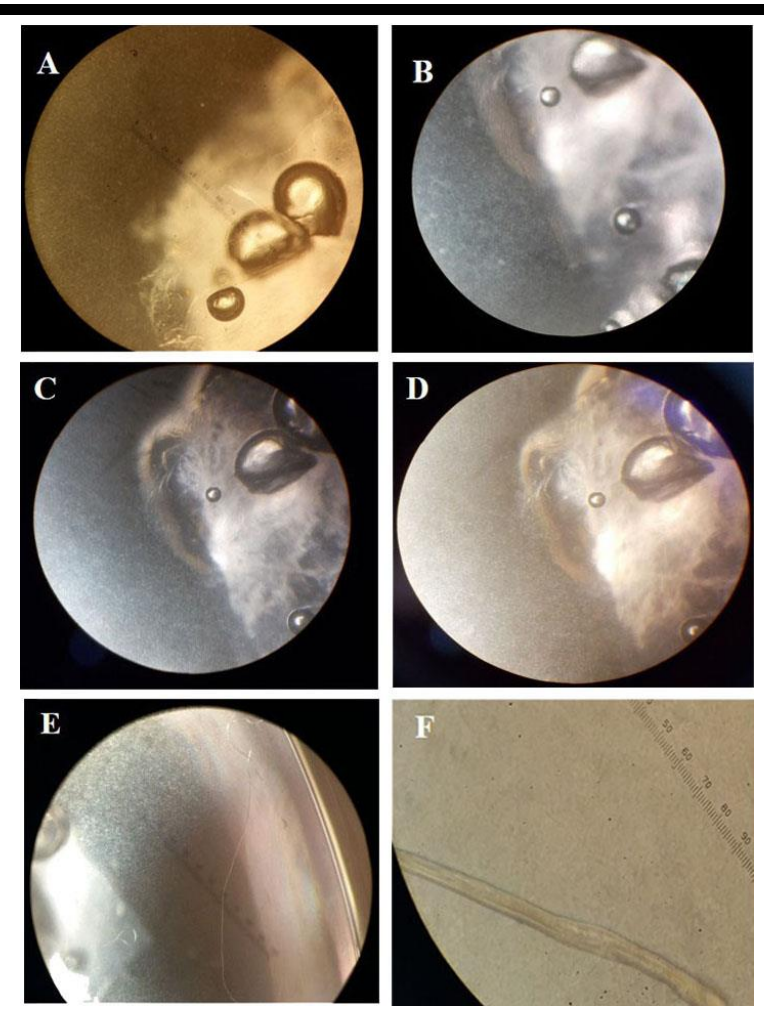

Figure 5. Observation of scaffold with cells under phase contrast microscope (4X magnification) at different time intervals A) 24 hours B) 48 hours C) 72 hours D) 96 hours E) 120 hours F) Appearance of muscle fibers after 120 hours of incubation (40X).

The scaffolds composed of collagen and chitosan are known to be biocompatible and are used for diverse applications. Ma et al. (2003) proposed a freeze-dried collagen chitosan porous scaffold for skin tissue engineering. Ahn et al. (2010) reported a collagen scaffold with precisely controlled pore structure for skin tissue engineering in which the keratinocytes and fibroblast cells were dispersed within the scaffold. Li et al. (2014) showed that the carrageenan chitosan gelatin scaffold was suitable for the attachment and proliferation of the adipose-derived mesenchymal cells. Apart from the biomedical application, the scaffolds can also be used for various other applications. Since 
the scaffold is made up of biocompatible and edible biomaterials, the application may extend to the food industry.

In vitro meat production is a recent concept in food biotechnology, and is also referred to as cellular agriculture, where the agricultural products are produced from plant or animal cells rather than the whole organism. They can involve either growing the edible part by means of an explant culture or by three-dimensional culture of tissue (Rubio et al., 2018). The process of production of the meat in vitro involves the culturing of the muscle cells in a three-dimensional network. Edible biomaterial-based scaffolds can be used in the in vitro meat production process for the three-dimensional cultivation of the tissue. In the current study, the materials used in the fabrication of the scaffolds are food related biomaterials. Carrageenan, chitosan and collagen are used in the food industry, and hence a scaffold fabricated using these materials were evaluated for compatibility with fish muscles as an initial step towards edible application. The biomaterials used in the fabrication of the scaffold were all derived from the wastes such as crustacean shell and skin of fish. The shells of crustaceans are considered as waste material by the food processing companies and approximately $60,000-80,000$ tons of shell fish wastes are disposed by these industries (Tarafdar and Biswas, 2013). The skin of cuttle fish is treated as waste at homes, fish shops and fish processing factories (Krishnamoorthy et al., 2017). Hence, they also prove to be economically viable.

In the present cell-based fish approach, the muscle cells of Trachinotus blochii were isolated and cultured along with the fabricated scaffolds. Earlier reports suggest that cells of marine molluscans and crustaceans can also be maintained in vitro. George and Dhar (2010) reported the maintenance of fibroblast cells and ovary-derived epithelial cells of crustaceans. Similarly, the cells of abalone were successfully maintained in M199 medium (Suja and Dharmaraj, 2005). Torres et al. (2016) cultured the muscles of fish to study the myostatin function in fish. The cells of other marine organisms can also be co-cultured with the scaffold for meat production.

Enrione et al. (2017) reported the growth of the Mus musculus muscle cells $(\mathrm{C} 2 \mathrm{C} 12)$ in the scaffold for meat production. A cost effective medium for the culturing of cells and identification of a plasticizer suitable for the type of cell used are necessary for the successful production of in vitro meat. The present study is a stepping stone for the production of marine food by means of the cellular agriculture.

\section{CONCLUSION}

The CCCW scaffold possesses all the characteristics required for an ideal scaffold. The scaffold production cost also proves to be cost effective as the materials used for the extraction of these marine bioactive compounds are industrial waste products. The scaffold supports the growth of fish muscle cells and can be used in the in vitro meat production. Further research and modifications are required. Modifications in the scaffold can also be made for better pore size and adherence of the cells to the scaffold. The successful growth of the cells in the scaffold can be beneficial in production of sea food without intense aquaculture systems. The current study is an initial study that shows the biocompatibility of the scaffold with the fish muscle cells.

\section{ACKNOWLEDGMENTS}

We would like to thank the Director, the Head of Marine Biotechnology Division and the Scientist-in-Charge, Tuticorin Research Centre of ICAR-Central Marine Fisheries Research Institute for facilitating the work. Our heartfelt thanks to Mr. Linga Prabhu, D., Scientist, TRC of CMFRI for providing the fish muscle tissue for this work. Further, we would like to acknowledge the laboratory assistance of Koncies Mary, B. and Muthukumar throughout the work. I would also like to thank the Research Scholars Ms. Gracy Angel and Ms. Jino Ancious for their encouragement and support.

\section{LITERATURE CITED}

Ahn, S.; Yoon, H.; Kim, G.; Kim, Y.; Lee, S., and Chun, W., 2010. Designed three-dimensional collagen scaffolds for skin tissue regeneration tissue engineering. Tissue Engineering: Part C, 16 (5), 813-820.

Chen, T.Y.; Huang, H.C.; Cao, J.L.; Xin, Y.J.; Luo, W.F., and Ao, N.J., 2016. Preparation and characterization of alginate/HACC/oyster shell powder biocomposite scaffolds for potential bone tissue engineering applications. RSC Advances, 6, 35577-35588

Chopin, T. and Whalen, E., 1993. A new and rapid method for carrageenan identification by FT IR diffuse reflectance spectroscopy directly on dried, ground algal material. Carbohydrate Research, 246, 51-59.

Coates, J., 2006. Interpretation of infrared spectra, A practical approach. In: R.A. Meyers (eds), Encyclopedia of Analytical Chemistry. John Wiley \& Sons, Limited.

Dodson, M.V.; Kinkel, A.; Vierck, J.L.; Cain, K.; Wick, M., and Ottobre, J., 2008. Unidentified cells reside in fish skeletal muscle. Methods in Cell Science, 56 (3), 171178.

Enrione, J.; Blaker J.J.; Brown I.D.; Weinstein-Oppenheimer, R.C.; Pepczynska, M.; Olguin, Y.; Sánchez, E., and Acevedo, A., 2017. Edible Scaffolds Based on NonMammalian Biopolymers for Myoblast Growth. Materials, 10(12), 1404; doi:10.3390/ma10121404.

Garg, T.; Singh, O.; Arora, S., and Murthy, R., 2012. Scaffold: A Novel Carrier for Cell and Drug Delivery. Critical Reviews in Therapeutic Drug Carrier Systems, 29 (1), 163.

George, S. K., and Dhar, A. K.,2010. An improved method of cell culture system from eye stalk, hepatopancreas, muscle, ovary, and hemocytes of Penaeus vannamei. In vitro Cellular \& Developmental Biology-Animal, 46 (9), 801-810.

Ha, T.B.; Quan, T.M.; Vu, D.N., and Si, D.M., 2013. Naturally Derived Biomaterials: Preparation and Application. Regenerative Medicine and Tissue Engineering, 247-274; doi: $10.5772 / 55668$.

Istini, S.; Ohno, M., and Kusunose, H., 1994.Methods of Analysis for Agar, Carrageenan and Alginate in Seaweed. Bulletin of Marine Science and Fisheries, 14, 49-55.

Krishnamoorthy, J.; Ramasamy, P.; Shanmugam, V., and Shanmugam A., 2017. Isolation and partial characterization of collagen from outer skin of Sepia pharaonis (Ehrenberg, 1831) from Puducherry coast. 
Biochemistry and Biophysics Reports, 10, 39-45

Li, J.; Yang, B.; Qian, Y.; Wang, Q.; Han, R.; Hao, T.; Shu, Y.; Zhang, Y.; Yao, F., and Wang, C., 2014. Iotacarrageenan/chitosan/gelatin scaffold for the osteogenic differentiation of adipose-derived MSCs in vitro. Journal of Biomedical Materials Research, 103 (7), 1498-1510.

Liu, Y.; Huang, Q., and Feng, Q. 2013.3D scaffold of PLLA/pearl and PLLA/nacre powder for bone regeneration. Biomedical Material, 8 (6), doi: 10.1088/1748-6041/8/6/065001.

Ma, L.; Gao, C.; Mao, Z.; Zhou, J.; Shen, J.; Hub, X., and Han, C. 2003. Collagen/chitosan porous scaffolds with improved biostability for skin tissue engineering. Biomaterials, 24 (26), 4833-4841.

Moutahir, B.F.; Balmain, N.; Lieberrher, M.; Borzeix, S.; Berland, S.; Barthelemy, M.; Peduzzi, J.; Milet, C., and Lopez, E., 2001. Effect of watersoluble extract of nacre (Pinctada maxima) on alkaline phosphatase activity and Bcl-2 expression in primary cultured osteoblasts from neonatal rat calvaria. Journal of Materials Science: Materials in Medicine, 12 (1), 1-6.

Nagai, T.; Yamashita, E.; Taniguchi, K.; Kanamori, N., and Suzuki, N., 2001. Isolation and characterisation of collagen from the outer skin waste material of cuttle fish (Sepia lycidas). Food Chemistry, 72 (4), 425-429.

Pereira, L.; Ana, M.; Amado.; Alan, T.; Critchley.; Velded, F.V.; Paulo, J.A., and Claro, R., 2009. Identification of selected seaweed polysaccharides (phycocolloids) by vibrational spectroscopy (FTIR-ATR and FT-Raman), Food Hydrocolloids, 23, 1903-1909.

Rubio, N.; Datar, I.; Stachura, D., and Krueger, K., 2018. Cellbased fish: a novel approach to seafood production and an opportunity for cellular agriculture. Preprints, 2018110326; doi: 10.20944/preprints201811.0326.v1

Sala, C.; Ribes, A.M.; Muiños, F.T.; Sancho, R.L., and Chicon, L.P., 2013.Current Applications of Tissue Engineering in Biomedicine. Journal of Bioengineering and Bioelectronics. doi:10.4172/2153-0777.S2-004.

Sharma, P.C. and Chandy, T., 1990. Chitosan-as a Biomaterial.
Biomaterials Artificial Cells and Artificial Organs, 18(1), $1-24$.

Silva, T.H.; Moreira, J.; Marques, L.P.; Domingues, A.; Bayon, Y., and Reis, R.L., 2014. Marine Origin Collagens and Its Potential Applications. Marine drugs, 12 (12), 58815901.

Suja, C. P., and Dharmaraj, S., 2005. In vitro culture of mantle tissue of the abalone Haliotis varia Linnaeus. Tissue and Cell, 37 (1), 1-10.

Tarafdar, A and Biswas, G., 2013. Extraction of Chitosan from Prawn Shell Wastes and Examination of its Viable Commercial Applications. International Journal on Theoretical and Applied Research in Mechanical Engineering, 2, 2319-3182.

Teli, M.D., and Sheikh, J., 2012. Extraction of chitosan from shrimp shells waste and application in antibacterial finishing of bamboo rayon. International Journal of Biological Macromolecules, 50, 1195-1200.

Toan, V.N., 2009. Production of Chitin and Chitosan from Partially Autolyzed Shrimp Shell Materials. The Open Biomaterials, 1, 21-24.

Tolnai, S., 1975. A method for viable cell count. Tissue Culture Association, 1, 37-38.

Torres, J.; Bautsita, E.; Sifuentes-Romero, I., and Gasca, T.G., 2016. A muscle-tissue culture system to study myostatin function in fish. In: Christensen, D (eds.), Protein biochemistry, synthesis, structure and cellular functions. Myostatin. Structure, role in muscle development and health implications. New York: Novinka, pp. 89-124.

Varun, T.K.; Senani, S.; Jayapal, N.; Chikkerur, J.; Roy S.; Tekulapally, V.B.; Gautam, M., and Kumar, N., 2017. Extraction of chitosan and its oligomers from shrimp shell waste, their characterization and antimicrobial effect. Veterinary World, 10, 170-175.

Venkatesan, J. and Kim, S.K., 2011. Introduction to marine biomaterials. In: Kim, S.K. (eds), Marine Biomaterials: Characterization, Isolation and Applications. CRC publications, pp 3-16. 